Jurnal Evaluasi Pendidikan, Vol. 2, No. 1, Maret 2011, 54-67

http://doi.org/10.21009/JEP

\title{
DEVELOPMENT OF EMOTIONAL QUOTIENT INSTRUMENT
}

\author{
Santi Lisnawati \\ Universitas Ibnu Khaldun, Bogor \\ Jl. KH. Sholeh Iskandar KM. 2 Bogor \\ santilisnawati@gmail.com \\ DOI: doi.org/10.21009/JEP.021.05
}

\begin{abstract}
The purpose of this research is to develop an instrument to measure emotional intelligence of high school students. The sample of this research was taken using multi stage random sampling technique. The instrument was developed using Thurstone scale, consisting of 90 items. A panel of judges was involved to review and select the items and based on the rational judgment; scores of scale (S), interquartile range (Q) were calculated, giving 45 items chosen. The instrument was tried out to 480 high school students in Bogor. Construct validity was calculated by using factor analysis. The result indicated that 5 factors were extracted from the data obtained by using exploratory method Principal Component Analysis (PCA), which is in accordance with the theoretical estimated factors; the confirmatory method used is the maximum likelihood (ML) to test the goodness of fit of the factors. The obtained index of test of the 5 factors is 1108,269. Therefore, it can be convinced that the correlation model of the five factors is valid. Alpha reliability is used to determine the reliability of the instrument $(\alpha=0,783)$. It can be concluded that the questionnaire measuring emotional intelligence has appropriate construct validity an internal consistency. Further tryout is still needed to standardize the instrument.
\end{abstract}

Keywords: instrument development, emotional intelligence 


\title{
PENGEMBANGAN INSTRUMEN KECERDASAN EMOSIONAL
}

\author{
Santi Lisnawati \\ Universitas Ibnu Khaldun, Bogor \\ JI. KH. Sholeh Iskandar KM. 2 Bogor \\ santilisnawati@gmail.com
}

\begin{abstract}
Abstrak
Tujuan dari penelitian ini adalah mengembangkan instrumen kecerdasan emosional siswa. Sampel penelitian ini diambil dengan menggunakan teknik multi stage random sampling. Pengembangan butir instrumen berdasarkan pada penilaian pakar dengan menggunakan skala Thurstone. Rancangan butir terdiri dari 90 butir pernyataan. Dari rancangan tersebut setelah dilakukan analisis penilaian pakar dengan menentukan nilai skala dan kualitas butir ( $\&$ \& $Q$ ) dihasilkan 45 butir yang terpilih. Kemudian instrumen diujicobakan kepada 480 siswa SLTA di Bogor untuk menentukan validitas konstruk dengan menggunakan analisis faktor. Hasil menunjukan bahwa terbentuk 5 faktor dengan menggunakan metode eksploratori atau Principal Component Analysis (PCA) faktor terbentuk sesuai dengan estimasi teoritik mengenai kecerdasan emosional, metode konfirmatori menggunakan maximum likelihood (ML) untuk menguji goodness of fit dari faktor. Didapatkan indeks dari kelima faktor tersebut yaitu 1108,269, karena itu dapat dikatakan bahwa model korelasi dari kelima faktor dianggap valid. Pengujian reliabilitas instrumen menggunakan Alpha didapat hasil $\alpha=0,783$. Dengan demikian dapat disimpulkan bahwa alat pengukur kecerdasan emosional telah memenuhi validitas konstruk dan reliabilitas. Pengujicobaan lebih lanjut masih tetap diperlukan untuk membakukan instrumen.
\end{abstract}

Kata kunci: pengembangan instrumen, kecerdasan emosional

\section{PENDAHULUAN}

Kecerdasan termasuk aspek psikologis yang dapat mempengaruhi kesuksesan individu atau keberhasilan siswa dalam belajar. Secara garis besar terdapat dua kategori kecerdasan yaitu intellective dan non intellective. Kecerdasan intellective disebut juga dengan kecerdasan kognitif, sedangkan kecerdasan non intellective meliputi kecerdasan-kecerdasan di luar kecerdasan kognitif yaitu kecerdasan emosional. Kecerdasan non-intellective menurut Wechler seperti yang dikutip Cherniss (2008: 2) bahwa, Wechsler was proposing that the non-intellective abilities are essential for predicting one's ability to succeed in life. Dengan demikian kecerdasan non intellective mampu memprediksi kesuksesan seseorang dalam hidup.

Kecerdasan emosional merupakan salah satu aspek yang dapat membantu kesuksesan belajar. Rahman (2008: 1) lebih jauh menyatakan bahwa banyak siswa di sekolah mengalami hambatan belajar karena faktor-faktor non intelektual, misalnya kenakalan remaja, tawuran, bullying, tindakan kekerasan lainnya. Kecerdasan emosional membantu agar kesulitan dan beban stres tidak 
melumpuhkan kemampuan berpikir sekalipun seseorang memiliki kecerdasan akademis yang tinggi. Menurut Goleman (2003: 113) mengatakan bahwa kecerdasan akademis praktis tidak menawarkan persiapan untuk menghadapi gejolak atau kesempatan yang ditimbulkan oleh kesulitan-kesulitan hidup. Kecerdasan emosi dan kecerdasan akademis keduanya saling menunjang dalam kesuksesan seseorang.

Dalam hal ini Candace Pert penulis Molecules of Emotion, dalam Given (2007: 38) menyatakan bahwa emosi menghubungkan tubuh dengan otak dan menyediakan energi untuk memacu prestasi akademis, kesehatan dan keberhasilan pribadi. Orang yang memiliki kecerdasan emosional yang baik dapat merujuk pada beberapa kerangka dasar yang diungkap oleh beberapa penggagas kecerdasan emosional. Salevey dan Mayer (1990: 6) mengemukakan definisi kecerdasan emosional dengan mengatakan kecerdasan emosional merupakan sejumlah keterampilan memproses informasi yang berhubungan dengan keakuratan penilaian tentang emosi diri sendiri dan orang lain, serta kemampuan mengelola perasaan untuk memotivasi, merencanakan, dan meraih tujuan kehidupan. Terdapat empat aspek dasar kecerdasan emosional yang dibangun Salevey dan Meyer yaitu: mengenali emosi, memahami emosi, mengatur emosi dan menggunakan emosi.

Kecerdasan emosional adalah kemampuan mengenali perasaan diri dan orang lain, kemampuan memotivasi diri sendiri, dan kemampuan mengelola emosi dengan baik pada diri sendiri dan dalam hubungan dengan orang lain. Kerangka kecerdasan emosional yang dibangun Goleman meliputi: 1) pengenalan emosi diri, 2) pengendalian emosi, 3) memotivasi diri sendiri, 4) mengenali emosi orang lain, dan 5) mengendalikan hubungan dengan orang lain. Selanjutnya kerangka kecerdasan emosional menurut Bar-On (2007: 39) bahwa, emotional intelligence is a multifactor array of interrelated emotional, personal, and social abilities that help us cope with daily demand. Kecerdasan emosional merupakan serangkaian kemampuan atau sekumpulan kecakapan yang saling berhubungan dan membantu seseorang untuk berhasil mengatasi tuntutan dan tekanan lingkungan. Terdapat lima dimensi yang dapat digunakan untuk mengukur kecerdasan emosional seseorang dalam konsep Bar-On (2007) yaitu: (1) intrapersonal, (2) interpersonal, (3) penyesuaian diri, (4) penanganan stres, dan (5) suasana hati umum.

Tujuan penelitian ini adalah untuk mengembangkan instrumen kecerdasan emosional secara umum dan secara khusus yaitu dimensi dan indikator apa saja yang mendasari konsep kecerdasan emosional dan bagaimanakah validitas serta reliabilitas instrumen kecerdasan emosional yang dikembangkan. Pengembangan instrumen kecerdasan emosional menggunakan konsep yang dipaparkan oleh Bar-On dengan beberapa alasan yaitu dimensi yang dikembangkan lebih komprehensif dan pengembangan alat ukur dapat digunakan dalam bentuk self report. 


\section{METODE PENELITIAN}

Penelitian ini menggunakan metode survei. Instrumen yang disusun merupakan atribut psikologis, dalam menyusun instrumen berkaitan erat dengan pemberian skor dan penskalaan. Metode yang berorientasi pada stimulus atau penskalaan stimulus digunakan untuk menentukan letak kontinum, kemudian angka yang dihasilkan dijadikan skor bagi butir yang disetujui. Dalam hal ini digunakan skala Thurstone metode interval tampak setara (method of equal appearing intervals).

Data isian dari responden dianalisis untuk melihat validasi konstruk, dengan menggunakan analisis faktor model PCA (Principal Components Analysis) dan ML (Maximum Likelihood). PCA digunakan untuk mengidentifikasi dimensi yang mendasar, atau mereduksi variabel tanpa kehilangan informasi yang berarti, sedangkan ML digunakan untuk menguji hipotesis yang berkaitan dengan pengelompokan variabel/jumlah faktor. Juga untuk melihat reliabilitas dari instrumen ini menggunakan reliabilitas alpha.

Kecerdasan emosional adalah sejumlah keterampilan yang berhubungan dengan keakuratan penilaian tentang emosi diri sendiri dan orang lain, serta kemampuan mengelola perasaan untuk memotivasi, merencanakan, dan meraih tujuan kehidupan, meliputi kemampuan yang terdiri dari: (1) intrapersonal, meliputi kesadaran emosi diri, sikap asertif, penghargaan diri, aktualisasi diri, dan kemandirian, (2) interpersonal terdiri dari empati, tanggung jawab sosial, serta hubungan antarpribadi, (3) penyesuaian diri terdiri dari uji realitas, dan sikap fleksibel, (4) penanganan stres terdiri dari ketahanan menanggung stres, dan pengendalian impuls, dan (5) suasana hati umum terdiri dari kebahagiaan, dan optimisme.

Variabel kecerdasan emosional yang hendak diukur berdasarkan kajian teori ditentukan dimensi dan indikatornya. Adapun dimensi dan indikator kecerdasan emosional disajikan pada tabel 1:

Tabel 1. Dimensi dan Indikator Instrumen Kecerdasan Emosional

\begin{tabular}{lll}
\hline No & \multicolumn{1}{c}{ Dimensi } & \multicolumn{1}{c}{ Indikator } \\
\hline 1 & Intrapersonal & $\begin{array}{l}\text { Kesadaran emosi diri, sikap asertif, penghargaan } \\
\text { diri, aktualisasi diri, dan kemandirian. } \\
\text { Empati, tanggung jawab sosial, dan hubungan } \\
\text { antar pribadi. }\end{array}$ \\
& Interpersonal & $\begin{array}{l}\text { Problem solving, uji realitas, dan sikap fleksibel. } \\
\text { Ketahanan menanggung stress, dan pengendalian } \\
\text { impuls. }\end{array}$ \\
4 & Penyesuaian diri & Penanganan stress \\
5 & Suasana hati umum & Kebahagiaan dan optimisme. \\
\hline
\end{tabular}

Langkah berikutnya adalah pengembangan instrumen, Margono (2005: 83) secara teknis pengembangan butir instrumen melewati beberapa langkah digambarkan pada gambar 1. 
Jurnal Evaluasi Pendidikan, Vol. 2, No. 1, Maret 2011, 54-67

http://doi.org/10.21009/JEP

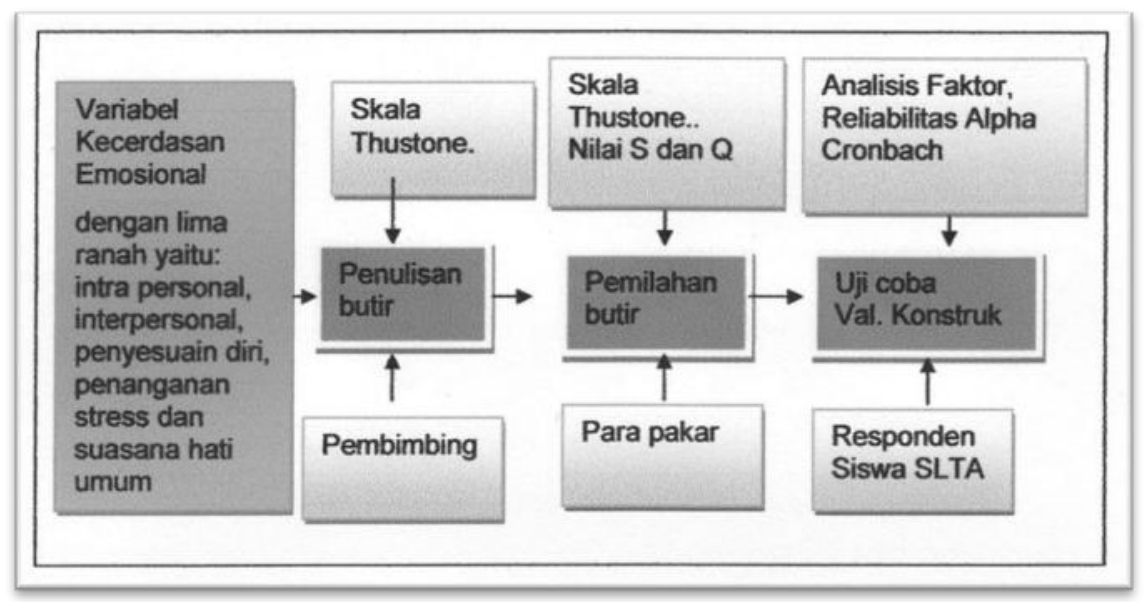

Gambar 1. Langkah Pengembangan Instrumen

Selanjutnya membuat kisi-kisi instrumen yang di dalamnya terdapat dimensi, indikator, butir negatif dan butir positif serta jumlah butir yang akan dibuat. Berdasarkan kisi-kisi instrumen kecerdasan emosional jumlah butir yang disusun sebanyak 90 butir. Jumlah butir pada setiap ranah ditentukan berdasarkan proporsional dari jumlah indikator, maka jumlah indikator yang banyak memiliki bobot persentase yang banyak pula, begitu pula sebaliknya. Dimensi dan indikator yang terdapat dalam variabel kecerdasan emosional tercerminkan dalam butir-butir pernyataan, butir-butir disusun berdasarkan kaidah penulisan menurut Azwar (2008: 52) .

Skala yang digunakan dalam instrumen kecerdasan emosional adalah skala Thurstone. Mueller (1986: 34) menyatakan bahwa Thurstone memiliki tiga teknik skala, namun yang digunakan dalam penelitian ini adalah teknik interval tampak sama (the method of equalappearing intervals). Kontinum interval skala Thrustone yang digunakan adalah $1-11$ atau (a - k). Thurstone membuat alat ukur dengan level skala interval, karena itu setiap butir memiliki skor berbeda tetapi jarak skor diantara butir dibuat sama. Suryabrata (2000: 204) memaparkan bahwa setiap butir dalam skala Thurstone yang digunakan dalam mengukur kecerdasan emosional sudah memiliki nilai. Nilai butir diperoleh melalui proses telaah pakar (professional judgment). Pemilihan butir pada skala Thurstone ditentukan melalui median sebagai harga skala (S) dan sebaran interkuartil (Q) sebagai ukuran variasi skala.

Dalam penelitian pengembangan instrumen kecerdasan emosional yang menjadi responden adalah siswa SLTA. Secara teoretik usia remaja ada pada kisaran 12-21 tahun. Untuk mendapat kestabilan karakteristik remaja maka diambil usia pertengahan yakni usia 16-17 tahun. Tempat penelitian adalah sejumlah sekolah (SLTA) yang terdapat di Bogor dengan proses random diperoleh tiga sekolah yang siswanya menjadi subyek penelitian. Adapun jumlah responden penelitian untuk pengembangan instrumen menurut Gable (1993: 39) menggunakan 6 sampai 10 kali lipat banyaknya jumlah butir dalam instrumen. 
Setelah terbentuknya butir pernyataan yang dibuat berdasarkan kisi-kisi adalah melakukan validasi isi. Hal ini dimaksudkan apakah butir-butir yang dibuat mencerminkan indikator yang dimaksud. Validasi ini merupakan pengujian tehadap butir pernyataan dengan analisis rasional melalui professional judgment atau kesepakatan pakar, adapun pakar yang menilai berjumlah 30 orang. Berikutnya menentukan validitas instrumen, setelah mendapatkan dengan terlebih dahulu melakukan uji coba instrumen kepada sejumlah responden. Hasil ujicoba dianalisis untuk menentukan validitas konstruk instrumen dengan menggunakan analisis faktor. Supranto (2004: 312) memaparkan langkahlangkah dalam analisis faktor adalah sebagai berikut:

1. Merumuskan masalah, yaitu variabel yang akan dipergunakan dalam analisis faktor harus dispesifikasi berdasarkan teori.

2. Menentukan matriks korelasi, agar analisis faktor bisa tepat dipergunakan variabel-variabel yang akan dianalisis harus berkorelasi. Statistik yang digunakan untuk menguji ketepatan model faktor adalah Bartlett's test of sphericity. nilai Keiser-Meyer Olkin (KMO) mengukur sampling adequacy suatu indeks yang digunakan untuk meneliti ketepatan analisis faktor. Nilai tinggi antara 0,5-1,0 berarti analisis faktor tepat.

3. Menentukan metode analisis faktor, dalam hal ini terdapat dua metode yaitu principal components analysis dan common factor analysis.

4. Menentukan banyaknya faktor berdasarkan nilai eigen value yang menunjukkan besarnya sumbangan dari faktor terhadap seluruh variabel asli.

5. Rotasi faktor, dimaksudkan agar setiap faktor memiliki muatan (loading). Sedangkan metode rotasi yang digunakan adalah varimax procedure.

6. Interpretasi hasil faktor, dengan mengenali berapa nilai loading terbesar pada faktor yang sama.

Selain ketepatan alat ukur kecerdasan emosional juga dituntut keajegan dari hasil ukur kecerdasan emosional. Koefisien reliabilitas menunjukan pada konsistensi skor pada subyek yang sama, saat diuji ulang dengan tes yang sama pada kesempatan yang berbeda atau dengan tes yang setara. Dengan demikian reliabilitas menunjukan sebuah konsistensi hasil yang didapat oleh responden pada beberapa kali dilakukan pengujian. Pengujian reliabilitas menggunakan koefisien reliabilitas Alpha Cronbach.

Ujicoba instrumen dilakukan oleh judges sebanyak 30 orang dengan rincian sebagai berikut: 1 orang doktor bidang PEP, 3 orang dosen psikologi Universitas Indonesia (UI), 6 orang dosen Psikologi Universitas Negeri Jakarta (UNJ), 2 orang dosen Psikologi universitas swasta, masing-masing dosen berlatar belakang pendidikan S2 Psikologi, 10 orang mahasiswa S2 PEP, dan 8 orang mahasiswa S2 Psikologi UI. Setelah judges memberikan penilaian dan catatan terhadap butir pernyataan, kemudian hasil penilaian dianalisis dengan cara 
menghitung nilai skala (S)/nilai butir dan nilai rentangan interkuartil (Q) atau kualitas butir.

Nilai butir atau nilai skala dihitung berdasarkan nilai median, sebab dalam psikometrika suatu perbedaan yang dapat dilihat diantara dua stimulus baru dapat dikatakan sebagai sesuatu yang dapat dibedakan apabila dilakukan oleh setengah dari jumlah seluruh responden atau $50 \%$ responden. Harga $S$ dan $Q$ ini dipakai untuk memilih pernyataan, makin kecil nilai $Q$, makin baik, karena hal ini menunjukan bahwa terdapat banyak kesepakatan antara penilai tentang bobot pernyataan. Dengan kata lain makin kecil nilai $Q$ makin homogen penilainya, kemudian dipilih pernyataan-pernyataan yang terletak di dalam interval yang kira-kira sama atau tampak sama (equal appearing interval).

\section{HASIL PENELITIAN DAN PEMBAHASAN}

Hasil pengembangan instrumen diperoleh bahwa nilai $\mathrm{S}$ terendah adalah 6,83 terdapat pada butir 52, sedangkan nilai $S$ yang tertinggi adalah 9,90 terdapat pada butir 33. Nilai $Q$ terendah adalah 0,31 terdapat pada butir 49, sedangkan nilai $Q$ tertinggi 6,96 terdapat pada butir 88 .

Kriteria pemilihan butir tersebut berdasarkan pada butir dengan nilai $S$ yang berinterval tampak setara, dan memiliki nilai $Q$ yang kecil. Dalam pemilihan butir dipilih butir yang memiliki interval di bawah 0,3 dan memiliki nilai $Q$ yang terkecil pada setiap kelompok nilai S. Sebagai contoh butir pernyataan nomor 40, 55 dan 74 memiliki nilai skala 8,90, maka dipilih butir yang memiliki nilai $Q$ terkecil diantara kelompok butir yang memiliki nilai $S$ yang sama yaitu butir 40 , dengan nilai $Q=1,81$. Jumlah butir setelah dilakukan penilaian pakar yang semula 90 menjadi 45 butir. Butir tersebut disusun kembali setelah dilakukan perbaikan redaksi kalimat pada butir-butir yang disarankan oleh penilai kemudian diujicobakan untuk menentukan validitas konstruk.

\section{Validitas dan Reliabilitas}

\section{Validitas}

Pelaksanaan ujicoba instrumen untuk validasi konstruk menggunakan butir yang telah divalidasi pakar sebanyak 45 butir pernyataan. Butir yang terpilih menjadi kuesioner yang akan diujicobakan kepada 480 siswa SLTA yang ada di Bogor. Validitas konstruk instrumen ini menggunakan analisis faktor. Analisis faktor merupakan suatu teknik statistik yang digunakan untuk mengidentifikasi sejumlah faktor atau mereduksi sejumlah faktor menjadi beberapa indikator tanpa kehilangan informasi yang berarti. Langkah awal analisis faktor dengan matriks korelasi berordo $45 \times 45$ memiliki determinan 0,01. Matriks tersebut merupakan hasil komputasi yang digunakan sebagai dasar rujukan analisis.

Hasil analisis diperoleh KMO sebesar 0,789. Nilai tersebut berada di atas 0,5 artinya analisis faktor tepat untuk menganalisis matriks korelasi yang tersebut. Nilai Bartlett test of sphericity diperoleh nilai Chi-square sebesar 
0,00347, dengan derajat kebebasan 990 dan taraf signifikansi kurang dari 0,01 $(p<0,01)$. Artinya matriks korelasi yang terbentuk bukan matriks identitas, maka analisis dapat dilanjutkan.

Setelah ditetapkan bahwa analisis faktor merupakan teknik yang tepat untuk menganalisis data yang dikumpulkan, kemudian dipilih metode yang tepat untuk analisis faktor. Dalam penelitian ini digunakan metode Principal Components Analysis (PCA).

Analisis berikutnya anti image matrices, dalam tabel analisis ini terdapat anti image correlation dengan nilai MSA (Measures of Sampling Adequacy). Ukuran kecukupan sampling untuk tiap varian ditampilkan dalam diagonal pada anti image correlation matriks. Kriteria MSA sebagai berikut: (1) bila MSA $=1$, artinya variabel dapat diprediksi tanpa kesalahan oleh variabel lain, (2) MSA>0,5, artinya variabel masih bisa diprediksi dan dapat dianalisis lebih lanjut, dan (3) MSA $<0,5$, artinya variabel tidak dapat diprediksi dan dianalisis lebih lanjut atau varian dikeluarkan dari analisis. Dengan melihat kriteria tersebut, tabel Anti Image Matrices untuk nilai MSA terendah adalah 0,543 dan MSA tertinggi adalah 0,869 , maka keseluruhan butir masuk dalam analisis lebih lanjut.

Selanjutnya diperoleh nilai communalities yang terdapat pada tabel 4 untuk butir 1 angka extraction 0,448 artinya 48,3\% variansi dari butir 1 dapat dijelaskan oleh faktor yang terbentuk. Persentase varians yang terbesar sebesar $46,3 \%$ dan yang terkecil yaitu $11,3 \%$.

Tabel 2. Communalities

\begin{tabular}{ccc}
\hline VAR & Initial & Extraction \\
\hline VAR00001 & 1,000 &, 448 \\
VAR00002 & 1,000 &, 355 \\
$\cdot$ & $\cdot$ & $\cdot$ \\
$\cdot$ & $\cdot$ & $\cdot$ \\
$\cdot$ & $\cdot$ & $\cdot$ \\
$\cdot$ & $\cdot$ & $\cdot$ \\
VAR00044 & 1,000 &, 284 \\
VAR00045 & 1,000 &, 140 \\
\hline
\end{tabular}

Extraction Method: Principal Component Analysis.

Penentuan banyaknya faktor dapat dilihat pada eigen value. Suatu eigen value menunjukan besarnya sumbangan dari faktor terhadap varians seluruh variabel asli. Hanya faktor dengan varian lebih besar dari satu yang diikutsertakan dalam model. Suatu eigen value mencerminkan jumlah varian (the amount of variance) yang berasosiasi dengan faktor.

Berdasarkan tabel total variance explained, dari 45 butir yang dimasukan dalam analisis faktor didapatkan eigen value lebih dari 1, dipilih 5 faktor terdapat pada tabel 6 . Hal ini sesuai dengan landasan teori kecerdasan emosional menu- 
rut Bar-On. Masing-masing nilai varian dari kelima faktor itu adalah muatan faktor pertama sebesar $12,383 \%$, kedua $5,641 \%$, ketiga 4,391\%, keempat 3,583\% dan kelima adalah $3,205 \%$. Secara kumulatif varians yang dijelaskan dari kelima faktor tersebut adalah berjumlah 29,203\%.

Plot dari eigen value dapat dilihat pada scree plot gambar 2. Dalam scree menunjukkan bagaimana kecenderungan penurunan eigen value yang dipakai untuk menentukan secara subyektif bayaknya faktor yang digunakan. Terlihat dari faktor pertama, kedua, hingga kelima arah garis terus menurun cukup tajam, kemudian turun hingga di bawah angka 1 pada sumbu $Y$ nilai akar karakterisistik (eigen value).

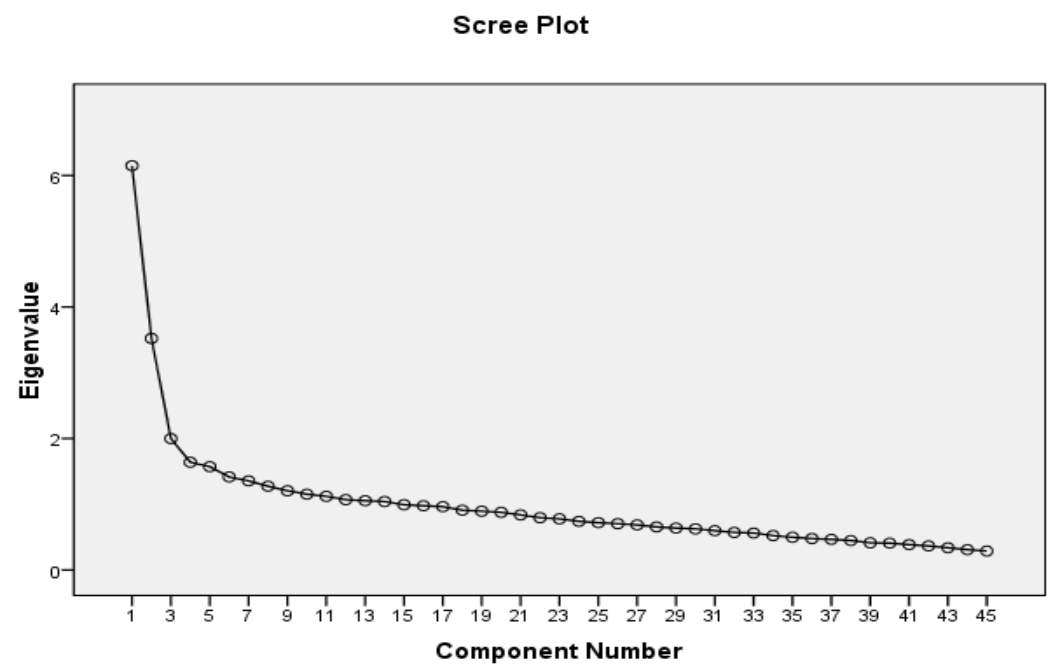

Gambar 2. Scree Plot

Tabel 3. Penyebaran Butir Kuesioner Kecerdasan Emosional

\begin{tabular}{|c|c|c|c|c|}
\hline Nama Faktor & $\begin{array}{l}\text { Nomor } \\
\text { Faktor }\end{array}$ & $\begin{array}{l}\text { Jumlah } \\
\text { Butir }\end{array}$ & Nomor Butir & Nomor Baru \\
\hline Intrapersonal & 1 & 14 & $\begin{array}{l}21,22,23,24,25,26 \\
27,28,29,30,31^{*} \\
32^{*}, 33^{*}, 34,35,36 \\
37\end{array}$ & $\begin{array}{l}19,20,21,22,23 \\
24,25,26,27,28 \\
29,30,31,32\end{array}$ \\
\hline Interpersonal & 2 & 9 & $1,2,3,4,5,6,7,8,9$ & $\begin{array}{l}1,2,3,4,5,6,7,8 \\
9\end{array}$ \\
\hline Penyesuaian Diri & 4 & 7 & $\begin{array}{l}38,39,40,41,42,43, \\
44,45^{*}\end{array}$ & $\begin{array}{l}33,34,35,36,37 \\
38,39\end{array}$ \\
\hline $\begin{array}{l}\text { Penanganan } \\
\text { Stres }\end{array}$ & 3 & 5 & $10,11,12,13,14$ & $10,11,12,13,14$ \\
\hline $\begin{array}{l}\text { Suasana Hati } \\
\text { Umum }\end{array}$ & 5 & 4 & $15^{*}, 16,17,18,1920^{*}$ & $15,16,17,18$ \\
\hline \multicolumn{2}{|c|}{ Jumlah Butir } & 39 & & \\
\hline
\end{tabular}

Keterangan: tanda $(*)$ artinya butir yang tidak di pakai. 
Selanjutnya melakukan rotasi, rotasi dilakukan agar variabel yang sudah berkorelasi dengan faktor tertentu tidak akan berkorelasi dengan faktor lain. Dalam merotasi faktor dikehendaki setiap faktor mempunyai loading. Kuatnya korelasi ditunjukan dengan nilai loading $\geq 0,30$. Hasil analisis menunjukan bahwa tidak ada butir yang melewati muatan faktor "cut off point" kurang dari 0,30 dan lebih dari -0,30. Setelah melalui rotasi 13 putaran atau iterations maka didapat nilai muatan faktor. Muatan faktor terbesar terdapat yaitu 0,667, dan terkecil 0,326 dan untuk muatan bernilai faktor negatif $-0,444$. Terdapat 39 butir yang valid dari 45 butir yang telah dipilih.

Butir-butir pernyataan kecerdasan emosional yang memiliki muatan faktor lebih kecil dari 0,30 dan lebih besar dari -0,30 serta nilai butir terdapat pada tabel 3. Berdasarkan hasil analisis dapat dinyatakan bahwa konstruk instrumen kecerdasan emosional telah sesuai dengan dimensi dalam kajian teoritis. Sebaran butir pernyataan dengan perubahan nomor disajikan dalam tabel 3.

Pada langkah selanjutnya, pendekatan konfirmatori dilakukan dengan metode kebolehjadian maksimum (ML) untuk menguji apakah estimasi hubungan 5 faktor yang telah lengkap berdistribusi normal multivariat. Komputasi dengan metode ML untuk menguji kesesuaian goodness of fit test. Menghasilkan indeks sebesar 1108,269 dengan derajat kebebasan 775 dan $p$ value kurang dari 0,01 .

Tabel 4. Goodness of fit Test

\begin{tabular}{ccc}
\hline Chi-Square & Df & Sig. \\
\hline 1108,269 & 775 & $3,1 \mathrm{E}-14$ \\
\hline
\end{tabular}

Dengan demikian maka dapat disimpulkan bahwa ujicoba kuesioner kecerdasan emosional yang dikembangkan telah memiliki validitas konstruk yang baik. Dengan analisis faktor metode ekploratori yaitu PCA dan metode konfirmatori yaitu ML. Selanjutnya karakteristik yang melekat pada instrumen selain validitas adalah reliabilitas. Reliabilitas adalah mengukur konsistensi hasil ujicoba, apabila suatu instrumen diberikan kepada subyek berulang kali akan meng-hasilkan skor yang konsisten atau tetap sama.

Pada instrumen kecerdasan emosional penghitungan reliabilitas empiris dengan menggunakan rumus Alpha Cronbach. Hasil penghitungan dengan bantuan program SPSS diperoleh koefisien reliabilitas sebesar 0,783 dengan demikian dapat dikatakan bahwa butir-butir instrumen kecerdasan emosional memiliki konsitensi internal yang cukup tinggi.

Dalam mengartikan kecerdasan tidak hanya selalu kecerdasan intelektual, meski kecerdasan intelektual merupakan modal keberhasilan dalam akademik, namun terdapat kecerdasan lain disamping kecerdasan intelektual yaitu kecerdasan emosional. Kecerdasan emosional memberikan kontribusi pada keberhasilan belajar serta kesuksesan hidup. Orang yang mengalami kecemasan tidak akan mampu berkonsentrasi baik, anak yang tidak mampu mengontrol 
emosi bisa jadi selalu terlibat dalam pertengkaran, hal itu akan menghambat kesuksesan belajar. Karena itu mengetahui kecerdasan emosi siswa sebagai bekal mengetahui kecer-dasan emosional diri merupakan hal yang perlu dilakukan.

Pengukuran kecerdasan dapat dilakukan dengan cara self report yaitu pengakuan sendiri apa yang dirasakan oleh siswa. Sebagaimana penggagas teori ini yaitu Bar-On mengklaim bahwa Emotional Quotient Inventory (EQ-i) sebagai alat ukur dengan cara lapor diri atau self report yang paling komprehensif. Dalam mengembangkan alat ukur kecerdasan emosional ini, melalui beberapa tahapan sebagai berikut:

1. Skala yang digunakan dalam mengembangkan instrumen ini yaitu menggunakan skala Thurstone. Dengan metode interval nampak setara (equal appearing intervals). Interval skala itu ditentukan oleh pendapat para subyek (judges). Thurstone dan Chave dalam Gable (1986) menggunakan median sebagai harga skala dan sebaran inter kuartil sebagai ukuran variansi skala. Dalam penelitian ini di dapat harga skala terendah adalah 6,83 terdapat pada butir 52, sedangkan nilai $S$ yang tertinggi adalah 9,90 terdapat pada butir 33. Untuk nilai $Q$ terendah adalah 0,31 terdapat pada butir 49, sedangkan nilai $Q$ tertinggi 6,96 terdapat pada butir 88. Setelah ditentukan interval yang diambil, maka terpilih 45 butir dari butir semula 90.

2. Menguji validitas konstruk intrumen menggunakan analisis faktor. Instrumen yang telah dipilah disusun sesuai masukan judges dan kriteria pemilihan butir, diujicobakan kepada sejumlah responden penelitian ini menggunakan 480 siswa SLTA sebagai responden. Hasilnya dianalisis dengan menggunakan analisis faktor. Yuliatri (2009) menuliskan bahwa analisis faktor dapat digunakan untuk menguji validitas suatu rangkaian kuesioner. Proses analisis faktor menggunakan program SPSS dengan tahapan sebagai berikut:

a. Menguji kelayakan analisis.

Dari hasil proses analisis faktor didapat nilai determinan 0.01 , menurut Supranto (1992) artinya matriks korelasi merupakan matriks nonsingular dan memiliki inverse, maka memungkinkan untuk uji lanjut. Nilai KMO 0,778 lebih dari 0,50, maka analisis lebih lanjut dapat dilakukan.

b. Menilai kecukupan sampling (MSA)

Uji ini untuk melihat nilai MSA (Measure of Sampling Adequacy). Jika variabel yang bertanda ${ }^{(a)}$ dengan letak diagonal pada matriks anti-image memiliki nilai kurang dari 0,5 maka variabel tersebut harus dikeluarkan dan proses diulang kembali, sampai didapat MSA lebih dari 0,5. Hasil analisis ini di dapat nilai MSA terendah adalah 0,543 yaitu butir 24, dan MSA tertinggi adalah 0,869 pada butir nomor 3. Dengan demikian keseluruhan butir masuk dalam analisis lebih lanjut.

c. Melakukan ekstraksi dan rotasi

Untuk butir 1 angka extraction 0,448 artinya 44,8\% varian dapat dijelaskan oleh faktor yang terbentuk. Persentase varians yang terbesar pada butir nomor 4 sebesar $46,3 \%$ dan yang terkecil sebesar $11,3 \%$ pada 
butir 20. Setelah melalui rotasi 13 iterasi maka didapat nilai muatan faktor. Muatan faktor terbesar terdapat pada butir 4 sebesar 0,667 dan terkecil pada butir 39 sebesar 0,326 serta muatan faktor negatif pada butir 10 yaitu $-0,444$. Dan terdapat 6 butir yang memiliki nilai muatan faktor dibawah 0,30 yaitu butir 15, 20,31, 32 dan 33, sehingga butir tersebut tidak digunakan. Dengan demikian terdapat 39 butir pernyataan yang terdapat dalam tabel muatan faktor yang termasuk valid. Total varian yang dapat dijelaskan dalam pengembangan instrumen kecerdasan emosional adalah sebesar 29,203\%. Masing-masing muatan faktor adalah pertama sebesar $12,383 \%$, kedua $5,641 \%$ dan terus menurun nilainya sampai pada muatan faktor kelima adalah 3,205\%.

d. Melakukan pendekatan konfirmatori

Pendekatan konfirmatori dilakukan dengan metode kebolehjadian maksimum atau ML untuk menguji apakah estimasi hubungan 5 faktor yang telah lengkap berdistribusi normal multivariat. Komputasi dengan metode ML untuk menguji kesesuaian goodness of fit test. Menghasilkan indeks sebesar 1108,269 dengan derajat kebebasan 775 dan probabilitas 0,00000031 , dengan demikian faktor berdistribusi normal.

Tabel 5. Rangkuman Hasil Analisis Faktor

\begin{tabular}{|c|c|c|c|}
\hline \multicolumn{3}{|c|}{ Eksploratori/PCA } & \multirow{2}{*}{$\begin{array}{l}\text { Konfirmatori/ML } \\
\text { Goodness of-fit }\end{array}$} \\
\hline Ekstraksi & \% Kumulatif & Verifikasi Butir & \\
\hline Faktor & & $\begin{array}{l}\text { Terhadap aspek } \\
\text { yang diukur }\end{array}$ & Test \\
\hline \multirow[t]{3}{*}{13 iterasi } & $29,203 \%$ & $\operatorname{Max}=0,667$ & $\chi^{2}=1108,269$ \\
\hline & & $\operatorname{Min}=0,326$ & $\mathrm{db}=775$ \\
\hline & & & $\alpha=0,01 \%$ \\
\hline
\end{tabular}

3. Reliabilitas hasil penghitungan dengan bantuan program SPSS diperoleh koefisien sebesar 0,783 dengan demikian dapat dikatakan bahwa butir-butir instrumen kecerdasan emosional memiliki konsitensi internal yang cukup tinggi.

Tabel 6. Reliabilitas

\begin{tabular}{cc}
\hline Cronbach's Alpha & N of Items \\
\hline 0,783 & 45 \\
\hline
\end{tabular}

\section{SIMPULAN}

Dari hasil penelitian ini maka dapat disimpulkan bahwa dalam menentukan dimensi dan aspek apa saja yang diukur dalam kecerdasan emosional merujuk kepada konsep kecerdasan emosional yang dikemukakan oleh Reuven Baron. Hal ini dipilih karena Bar-On memiliki dimensi kecerdasan 
emosional yang berbeda, komprehensif dan belum banyak dikembangkan oleh orang. Adapun dimensi dan aspek yang diukur dalam kecerdasan emosional yang dikembangkan dalam penelitian ini adalah terdiri dari 5 dimensi dan 15 aspek yang diukur, yaitu: (1) intrapersonal yang terdiri dari; kesadaran emosi diri, sikap asertif, penghargaan diri, aktualisasi diri, kemandirian, (2) interpersonal yaitu terdiri dari; empati, tanggung jawab sosial, dan hubungan antar pribadi, (3) penyesuaian diri yaitu terdiri dari; pemecahan masalah, uji realitas, dan sikap fleksibel, (4) penanganan stres terdiri dari; ketahanan menanggung stres dan pengendalian impuls, dan (5) suasana hati umum, terdiri dari; kebahagiaan dan optimisme.

Instrumen kecerdasan emosional disusun berdasarkan skala Thurstone, jumlah butir yang dikembangkan sebanyak 90 butir. Setelah melalui tahap pemilahan oleh judges dan dihitung nilai skala (S) dan interkuartil (Q) serta interval yang diambil maka terdapat 45 butir yang terpilih. Validitas Instrumen kecerdasan emosional menggunakan validitas konstruk dengan menggunakan analisis faktor. Dari 45 butir setelah dilakukan validitas konstruk diperoleh 39 butir. Metode yang digunakan yaitu PCA atau ekploratori, dihasilkan 5 faktor yang diekstraksi, sesuai dengan dimensi yang diestimasikan. Dan metode konfirmatori/kebolehjadian maksimum terdapat kesesuaian goodness of fit test yang signifikan.

Pada instrumen kecerdasan emosional penghitungan reliabilitas dengan menggunakan rumus Alpha Cronbach, koefisien sebesar 0,783. Dengan demikian dapat dikatakan bahwa butir-butir instrumen kecerdasan emosional memiliki konsistensi internal yang cukup tinggi.

\section{DAFTAR PUSTAKA}

Azwar, Saifuddin. (2008). Penyusunan Skala Psikologi. Yogyakarta: Pustaka Pelajar.

Bar-On, Reuvan. (2001). Emotional Intelligencel and Self Actualization. Philadelphia: Psychology Press.

Cherniss, Cary. (2000). Emotional Intelligence: What it is and Why Metters.". http://www.eiconsortium.org/pdf/what_is_emotional_intelligence.pdf.

Gable, Robert K. (1993). Instrumen Development In The Affective Domain. Boston: Kluwer Academic Publisher.

Gardner, Howard. (1983). Frames of Mind. New York: Basic Books. 
Given, B. K. (2007). Brain-Based Teaching.Terjemahan Lala Herawati Dharma. Bandung: Mizan.

Goleman, D. (1998). Working with Emotional Intelligence. London: Bloombury Publishing.

Goleman, D. (2003). Emotional Intelligence. Terjemahan T. Hermaya. Jakarta: Gramedia.

Margono, Gaguk. (2005). “Pengembangan Instrumen Pengukur Afeksi terhadap Matematika."Disertasi, Pascasarjana Universitas Negeri Jakarta.

Mueller, Daniel J. (1986). Measuring Social Attitudes. London: Teacher College Press.

Rahman, Arief. (2008). Wacana Pendidikan. Koran Tempo, 4 Desember.

Salevey, P., dan J. D Mayer. (1990). Emotional Intelligence, http://www.unh.edu /emotional_intelligence/EIAssets/Reprints...EIProper/EI1990EmotionalIntel ligence.pdf.

Supranto, J. (2004). Analisis Multivariat, Arti dan Interpretasi. Jakarta: Rineka Cipta.

Suryabrata, Sumadi. (2000). Pengembangan Alat Ukur Psikologis. Yogyakarta: Andi. 